\title{
Succinylcholine Chloride
}

National Cancer Institute

\section{Source}

National Cancer Institute. Succinylcholine Chloride. NCI Thesaurus. Code C47730.

The chloride salt form of succinylcholine, a quaternary ammonium compound and depolarizing agent with short-term muscle relaxant properties. Succinylcholine chloride binds to nicotinic receptors at the neuromuscular junction and opening the ligand-gated channels in the same way as acetylcholine, resulting in depolarization and inhibition of neuromuscular transmission. Depolarization may be prolonged due to succinylcholine's resistance to acetylcholinesterases thereby leading to disorganized muscle contraction followed by skeletal muscle relaxation and flaccid paralysis. 